\title{
The evolution of security industry regulation in the European Union
}

\author{
Mark Button and Peter Stiernstedt \\ Institute of Criminal Justice Studies, University of Portsmouth, Portsmouth, UK
}

Word count: $\quad 7858$

Corresponding author: Peter Stiernstedt

E-mail: $\quad$ peter.stiernstedt@ port.ac.uk

Phone: $\quad$ +44 $\quad$ + $\quad$ +

\section{Key words}

private security, regulation, European Union, security industry, security directive

\begin{abstract}
The European private security sector has grown from a handful of small companies at the end of the Second World War into a multi-billion Euro industry with thousands of firms and millions of security staff. In Europe the demands for security is not just expressed notionally but also officially in The European Agenda on Security stating the European Union aims to ensure that people live in an area of freedom, security and justice. This paper will begin by exploring the role of private security in society. It will then move on to consider the main phases in the development of private security regulation in Europe. Following on from this some of the main areas of policy development will be considered, such as European bodies, initiatives and standards. Finally the paper will explore some of the potential op tions for the future in better regulating the European private security sector. From a historical perspective the evolution of private security regulation can be divided into three phases; the Laissezfaire, the centrifugal and the centripetal era - each with its own distinct characteristics and impact on the concurrent industry. In the European Union where there is the legal framework for the development of a single market in services the key social partners have been at the forefront of developing a series of standards and guidance documents which promote standards across borders at the European level. However, the institutions of the European Union have been reluctant to intervene at a European level in setting minimum standards of private security regulation. Thus, the changing terrain of the European Union relating to security, regulation and the private security industry mean the current trajectory may be in need of an injection of more radical thought and consideration.
\end{abstract}




\section{Literature review}

\section{Introduction}

The European private security sector has grown from a handful of small companies at the end of the Second World War into a multi-billion Euro industry with thousands of firms and millions of security staff. Indeed the Confederation of European Security Services (COESS), which represents a significant part of the European manned guarding sector of the industry (but not all), claims to represent members covering over 60,000 security companies, 2.2 million employees with a turnover of over $€ 34.2$ billion in 19 EU member states and a total of 24 countries within Europe (COESS, n.d.). The breadth of activities undertaken by the private security sector in the European Union also varies significantly between states, but in most the trajectory has been one of increasing movement towards tasks traditionally associated with state provided security services. Some of the functions now popularly undertaken in the European Union include the provision of security at major places of public

gathering as well as the security of places of critical national infra-structure, and in some countries the sector even guards and transports prisoners, monitors prisoners under supervision with electronic tags, patrols residential streets, guards crime scenes and undertakes some parts of police investigations (Van Steden, 2007; CoESS, 2011; UNODC, 2014).

To give an idea of the proliferation of private security personnel this means a presence at locations such as shopping centres, leisure parks, transport hubs, pop concerts, sporting events; airports, government facilities, military bases, nuclear power stations, courts etc. The list goes on and on, resulting in daily interactions with the ordinary citizen of Europe more common than not. Further, in some states security staff regularly carry arms or other nonlethal weapons (UNODC, 2014). The Weberian 'totem' of the state as holding the 'monopoly of legitimate use of force' has been significantly cracked by the rise of private security. Even the 'arms length' control of the private security as contractors for the state has been accompanied with equally if not larger growth of 'nodes' or pockets of governance, beyond the state in the private and voluntary sectors, in which private security plays a significant part, often using 'legitimate force' amongst other strategies to secure compliance (Johnston \& Shearing, 2003; Button, 2008). Such profound changes, combined with the increasing demands of states and citizens for greater security have stimulated both national and European level interest in shaping, controlling and making accountable the private security sector.

In Europe the demands for security is not just expressed notionally but also officially as set out in the Stockholm program (2010) and then reinforced in The European Agenda on Security (2015) the European Union aims to ensure that people live in an area of freedom, security and justice. With the complex and often asymmetrical threats faced by modern societies this has increasingly meant the need for further synergies and cooperation at all 
levels. The new variables of international borderless threats, the dynamic nature of globalisation and the ensuing decrease of importance of geographic location are changing the face of security worldwide. State driven security with policing, as one of its primary weapon of choice is no longer enough and in many Member States the private security industry has assumed a substantial position in the provision of policing (Jones \& Newburn, 2006; Ocqueteau, 2006; Van Steden \& Sarre, 2007; CoESS, 2011). Private security as a response to the recognition of globalisation as a cause for growing societal complexity spawning ever more intricate threat dimensions is not something entirely new. In their paper 'Modern Private Security: Its growth and Implications' Shearing and Stenning (1982) suggested that private security was moving in the direction of a new disciplinary society and raised fundamental questions with respect to sovereignty, justice, and individual liberty at the time almost entirely unrecognized. Today the questions are certainly recognised, often debated and given high priority on the European political agenda. Nonetheless, inter-state disagreement persists and supra-national policy does not always align with national ones. Even less so when comparing the ambitious rhetoric with actual achievements, with a largely varied level of private security regulation throughout Europe (Button \& Stiernstedt, 2016).

Despite persisting regulatory variance, since the end of the Cold War the privatisation of security in Europe is developing rapidly where the new security 'fashion' is for developed nations to adopt a national security doctrine with increasingly specialised police functions, with non-core security functions increasingly outsourced to the private market. This development and growth of private security has consequently also been a key factor behind the expansion of security industry regulation. As more and more people have come into contact with security personnel or become dependent on security technology, there has been an increasing recognition of the need for better management of these encounters and relationships (Prenzler \& Sarre, 2012). The response itself has evolved with the growth of the private security industry and now includes elements of regulation, and thereby cleansing the market of deviant providers, to efforts to communalize by equalizing access to the security market. The most recent evolutionary step suggested is towards a civilizing model with the regulatory goals being inclusive deliberation and social solidarity (Loader \& White, 2015). Presented as a model this final step is perhaps better viewed as another smaller, yet not insignificant, nonetheless chronologically subsequent - both in appearance and implementation, piece of an increasingly fine tuned regulatory melody harmonizing throughout Europe.

Notwithstanding, the private security industry to this day is continuing to grow, an inexorable fact that has been attributed to a wide variety of factors (Shearing \& Stenning 1982; Jones \& Newburn 2006). Deliberate policies of privatising policing have not been particularly significant (Prenzler \& Sarre, 2012). The evolution of private security and the regulation thereof is a noteworthy topic and has been investigated in different regions of the world such as Australia (Prenzler \& Sarre, 2012) and Africa (Abrahamsen \& Wiliams, 2005; 
Kasali, 2012). Also in Europe the issue is being addressed both by academics and policy makers (De Waard, 1999; Button, 2007a; CoESS, 2011).

This paper will begin by exploring the role of private security in society. It will then move on to consider the main phases in the development of private security regulation in Europe. Following on from this some of the main areas of policy development will be considered, such as European bodies, initiatives and standards. Finally the paper will explore some of the potential options for the future in better regulating the European private security sector.

\section{The role of private security in society}

The rate of growth in size of the private security sector is paralleled only by the concurrent expansion in role and responsibility. This inevitably leads towards an increase of importance (or at least relevance) of the issue, politically and practically, being elaborately weaved into the fabric of modern society. Currently many of the functions traditionally assumed by the public police are now undertaken by private security (Jones \& Newburn, 1998; Hainmuller \& Lemnitzer 2003; Gimenez-Salinas, 2004; Ocueteau, 2006; Van Steden, 2007; Button, 2007b; CoESS, 2011). Further, as recent events have shown in failing states when law enforcement agencies are discredited reformers turn to creating parallel private security structures (The Economist, 2015). Then, in a sense, completely replacing the traditional function of the police and state monopoly on, not only providing security but also, enacting force and violence.

The sheer speed with which the private security industry is evolving puts a heavy strain on regulation to keep up. Although, most countries in the EU have already put in place a range of legal, practical and supporting mechanisms to underpin a Europe of, if nothing else, internal security. Some countries in the EU actually bear the hallmark of having implemented some of the most demanding regulatory systems in the world (Prenzler \& Sarre, 2008; Button, 2008). Nonetheless, as many studies have shown, the systems vary considerably in content (De Waard, 1993; Button, 2007a; 2012; CoESS, 2011, Button \& Stiernstedt, 2016). While covered by significantly less research the same is arguably true for the level of actual efficiency i.e. societal impact of the regulation or lack thereof.

With the expansion of private security sometimes interpreted as a sign of economic growth and as an adjunct to more capitalistically influenced market economies. Together with rising crime rates often appearing in tandem with economic growth, in turn pushing for further expansion of the private security market both in size and reach. As always correlation does not imply causation but it does make for a solid argument of private security and the regulation thereof evolving symbiotically with society as a whole. It is and will remain an ever more pressing concern on all levels of Europe, national as well as supranational, for governments and NGOs alike. So how has the private security regulation evolved throughout history to its meritorious place as an integral and essential part of 
modern society?

\section{Method}

\section{An historical account of the phases of PSR from a European perspective}

Reviewing the literature available on the topic of private security regulation, the evolution thereof may be divided into at least three distinct phases. The extent to which various concepts within the discipline are adequately covered by extant literature varies and the diversity of sources called for a systematic methodology to map the territory. The method applied is informed by the rigorous system proposed by Wolfswinkel, Furtmueller \& Wilderom (2013), assuring in-depth analysis of empirical facts and related insights. The five stage process of the method consists of define, search, select, analyse and present and can be considered as a means by which central literature and underpinning research can be systematically mapped out for in-depth analysis. Having said that, the final methodology applied does not consist of totally rigid and sequential analysis, but actually rather moves away from such prescriptive constructs letting the analytical system act as a conceptual framework within which the qualitative analysis resides. This allowed the interrelationships, dependencies and inconsistencies, in (and to some extent beyond) the particular topic to be explored. This produced a policy-piece type result, formulated as; from a historical perspective the evolution of private security regulation can be divided into three phases; the Laissez-faire, the centrifugal and the centripeta $1^{1}$ era - each with its own distinct characteristics and impact on the concurrent industry.

\section{Laissez-faire Europe 1930s to mid 1970s}

The antecedents of the private security industry can be traced back many hundreds of years if roles such as watchmen and locksmiths are considered (George \& Button, 2000). The first private security companies in their modern form began to be formed in the early nineteenth century. The emergence and substantial growth in the private security industry, however, can be traced to the post-war period, particularly from the 1960 s onwards (Jones \& Newburn, 1996; George \& Button, 2000). Regulation of private security, however, has some unexpected origins in this period. For example in both Belgium and the Netherlands legislation was passed in the 1930s to regulate fascist militias, which was sufficiently wide in scope to be used to regulate the emerging and fast growing private security sector some years later (De Waard \& Van Der Hoek, 1991; De Waard, 1996). For most of Western Europe the early expansion was accompanied with industry self-regulatory measures to try and set and raise standards. This period was characterised by little European level interest with states and national private security industry groups largely pre-occupied with their own

\footnotetext{
${ }^{1}$ Centrifugal denotes a force directed outward from an orbital centre as opposed to centripetal force directed inwards. The nomenclature is used to conceptualise and no distinction is made insofar that in reality centripetal force is an actual force and centrifugal force is an apparent force.
} 
country and regulatory needs (De Waard \& Van Der Hoek, 1991).

\section{Centrifugal Europe mid 1970s to early 1990s}

Rapid expansion of the private security industry, the important roles it was beginning to secure, along with a variety of problems associated with the sector, triggered debates in many countries over whether statutory regulation of some form should be introduced. Some states used existing statutes, not specifically designed for private security, such as the Netherlands (De Waard, 1999); some introduced special regulation, such as Spain (various laws and regulations between 1978-1981); other resisted, for ideological reasons (UK) or simply because the industry had not developed significantly or did not exist (Greece, Eastern communist states). However, from the mid 1970s and during the 1980s there were a group of Western European countries beginning to introduce statutory regulation. These countries, however, legislated according to their own needs with little reference for a common European approach. The forces for regulation were creating very different approaches to regulation of private security in the countries which were already part or destined to be part of the European Union (De Waard \& Van Der Hoek, 1991).

\section{From Centrifugal to Centripetal Europe early 1990s onwards}

In 1990 the EU consisted of 12 states and of these all bar Greece, the Republic of Ireland and the United Kingdom had some form of regulatory system for the private security sector. However, in countries such as Germany regulation was based upon general trade legislation and was minimal. In Belgium and the Netherlands it was based upon laws designed for private militias and in Italy too on dated legislation from the 1940s. A report published for the Dutch Ministry of Justice in 1991 noted the significant variations across Europe in regulation, particularly upon training (De Waard \& Van Der Hoek, 1991). The UK, Republic of Ireland, Greece were still to regulate and relied to varying extents on selfregulatory measures. Most countries were looking towards their own regulatory needs with little reference to the rest of Europe. However, the report for the Dutch Ministry of Justice showed some countries were beginning to look at what other countries were doing and to consider wider European implications (De Waard \& Van Der Hoek, 1991). Significant changes began to emerge from the early 1990s, however, with a variety of developments occurring which have increased the needs for greater European co-operation and harmonisation, shifting the force from centrifugal to centripetal.

The creation of the European single market in the European Union unleashed the foundations of free movement of labour, undertakings and services within the European Union. The former communist countries of Eastern Europe shook off their Soviet masters, many enthusiastically looking to and embracing their Western neighbours ways of doing things and of course most eventually joining the European Union, along with some of the remaining Western European countries who were outside. The expansion to Eastern Europe 
also substantially increased movement of citizens around the European Union. In the UK, for instance, over the last decade 2.5 million have migrated to the UK, with a significant proportion of these from the EU and particularly Eastern Europe (Barrett, 2014). Indeed in 2011 there were estimated to be almost 700,000 Poles alone who had emigrated to the UK (Okolski, 2014).

Underneath these macro developments a variety of security level developments also emerged adding to the growing centripetal forces. Large global security companies have emerged operating in multiple states of the European Union: G4S, Securitas and Prosegur. For example G4S has over 600,000 employees operating in 110 countries throughout the world generating $£ 6.4$ billion of revenue (G4S, 2016). Security risks have increased substantially, particularly vis-à-vis terrorism, organised crime and increasingly cyberdevelopments (Control Risks, 2016).

Acting as a barrier to some of these forces have been the regulatory systems for private security, which at the time of writing consists of 28 EU Member States. These vary significantly in the standards that are applied to the private security industry. This is illustrated by, for example CoESS facts and figures for private security services in Europe (2013) providing a rating on the strictness of private security legislation for each country. Here a numerical value was allocated to each country on the basis of the answers to a questionnaire. Through a points allocation system five judgment criteria were devised: very strict $^{2}$, strict ${ }^{3}$, medium ${ }^{4}$, low ${ }^{5}$, weak or non-existent. Indicating the different levels of regulatory strictness on a national level.

Along the same lines, although applying a significantly more sophisticated and detailed analysis, Button \& Stiernstedt (2016) have also assessed the regulatory systems. Based on a variety of criteria drawn from guidance such as the UNODC (2014) guidance on regulation, the ECORYS (2011) report on security regulation as well as previous research by Button (2007a), amongst several others. A maximum of 100 points was possible and of the 26 states that were assessed the points ranged from 94/100 in Belgium to 22/100 in the Czech Republic. Broadly the European Union countries can be sorted according to the following regulator typology; super $^{6}\left(75+\right.$ points), strong ${ }^{7}$ (50-74 points), weak ${ }^{8}$ (25-49 points) and

\footnotetext{
2 Serbia, Hungary, Belgium, Sweden, Portugal, Spain, Luxembourg

3 Turkey, Greece, Macedonia, Romania, Bosnia and Herzegovina, Croatia, Slovenia, Slovakia, Italy, Switzerland, The Netherlands, Estonia, Lithuania, Denmark, Norway, Finland, Malta

4 Ireland, United Kingdom, France, Germany, Bulgaria, Latvia, Cyprus

${ }^{5}$ Austria, Czech Republic, Poland

${ }^{6}$ Belgium, Spain, Slovenia, Greece, Portugal, Sweden

7 Ireland, Finland, Romania, Luxembourg, Germany, Malta, France, Netherlands, Estonia, Poland, Denmark, Latvia, Bulgaria, United Kingdom, Slovakia

8 Italy, Cyprus, Lithuania, Austria
} 
quasi $^{9}$ (24 points and below).

This distinction is purely based upon the points achieved by the country, with those with 75 points or more meeting the highest standards, hence 'super regulators', those with 50 to 74 doing well, but not in the elite, nevertheless 'strong regulators'. Then there are the countries with significant gaps in there systems and hence, 'weak regulators' and finally the example of the Czech Republic, which is so weak it could even be considered as a 'quasi-regulator'. To highlight this difference a security officer in the Czech Republic has no mandatory number of hours of training to start working in the industry, which compares to one in Sweden who has to complete close to and in excess of 300 hours depending on role.

\section{Findings}

\section{European organisations and their relationship with PSR}

The need to turn the tide away from the centrifugal forces was identified in the late 1980s by some European security organisations, which culminated in structures and organisation being created to push for various harmonisation related measures. This 'turning of the tide' toward s centripetal forces can be traced to the formation of a number of influential European bodies dedicated towards lobbying European institutions for actions more favourable to the European security industry. Notably CoESS was formed in 1989 bringing together the national trade associations for the manned guarding sector in the member states and candidate member states. CoESS, however, was not the first such European body and was preceded by several more security technically focussed bodies such as EUROALARM (1970), EUROSAFE (1988) and ESTA (1976) and EASEM in 1987. More recently the European Organisation for Corporate Security (EOCS) was created in 2005 and the European Organisation for Security (EOS) in 2007. Some of these organisations had been created with a greater focus on standardisation bodies, such as EUROALARM, rather than the EU. In contrast, CoESS, followed some time later by EOCS and EOS, are predominantly orientated towards the institutions of the European Union and as will be shown has engaged in a wide range of activities that have contributed towards centripetal forces on regulation. Parallel to the employers bodies trade unions representing security officers across Europe had been working through UNI-Fiet (now Europa) to support centripetal initiatives. In 1991, for example, there was a motion to the European Parliament calling for European harmonisation of regulation (George \& Button, 2000: 182-3).

The turning point towards a period becoming concerned with the need for greater harmonisation, however, can be traced to the work of the European Commission Directorate General V in partnership with CoESS and Uni-Fiet conference in London in 1996, where COESS and UNI/Fiet signed a joint agreement on vocational training. The declaration made very clear the first centripetal shift of thinking amongst the key social partners in the

${ }^{9}$ Czech Republic 
European Union, stating:

The social partners have been co-operating in a number of ways on the issue of vocational training. A project under the European Union's FORCE Programme was carried out during 1994. This European perspective provides the basis for deepening cooperation between the social partners on the subject of vocational training. It has allowed the defining of common occupational profiles described in terms of the tasks which security operatives carry out. This provides the basis for developing a common European approach to vocational training in the European security industry which highlights the best from each national context whilst respecting the diversity in national practices and training structures which exist (COESS, 1996).

This has been followed by much more work between the social partners developing joint declarations and standards, which will be discussed in more depth shortly. However, the most significant development between the social partners was in 2001 when the social partners signed the 'Joint declaration of CoESS and UNI-Europa on the European harmonisation of legislation governing the private security sector (CoESS, 2001). The declaration noted the problem of, amongst others:

National regulations differ from one another and they prevent the sector from drawing on the full benefits of European integration.

And it went on,

...CoESS and UNI-Europa therefore call on the European ministers responsible to take the necessary measures so that the private security sector is governed by laws aimed at ensuring high quality standards and a high degree of professionalism in all countries of the European Union, and so that European harmonisation of the following aspects can be developed (authors emphasis):

These aspects included: authorisations to practice (workers), licences (companies), evaluation and supervision by public authorities, professional training, health and safety, working conditions and the provision of cross-border services. This was a significant call for the institutions of the European Union to create supra-national structures to facilitate commons minimum standards across a wide range of areas.

A few years later the European Union did offer a centripetal initiative for the private security sector, but of a deregulatory flavour which was unpalatable to most of the European security industry. In January 2004 the European Commission published a draft Directive with the aim of creating a real internal market for services. The services covered amount to around 50 per cent of economic activity of the EU and the Directive explicitly included security services. The Directive fuelled much debate over the future direction of Europe. In the context of private security, however, CoESS opposed the Directive seeking exemption for 
private security or significant changes to it. This rested on two concerns; first, the Directive's aspiration to get rid of 'authorisation schemes', which would mean the licensing structures that exist in most countries and second the 'country of origin' principle, where a provider legally operating in one Member State could market its services in another without having to comply with their regulations (CoESS, 2004).

These concerns were amplified at the time with the accession of Cyprus and the Czech Republic, who at that time had no or virtually no regulation. Unchanged the Directive could have resulted in companies from countries with lesser regulatory systems moving to those with higher standards and under-cutting them; returning the security sector to the old downward spiral in standards, which is what regulation was introduced to address in most countries. However, after intensive lobbying of Members of the European Parliament, by COESS and other organisations, the Directive was amended to exclude the security sector (amongst others) in a vote on the $16^{\text {th }}$ February 2006 (COESS, 2006).

\section{European standards}

In the European Union where there is the legal framework for the development of a single market in services the key social partners have been at the forefront of developing a series of standards and guidance documents which promote standards across borders at the European level. The key partners: COESS (security company trade associations) and Uni-Europa (trade unions) have developed the following, which seek to set standards for private security regulators, companies and operatives across the European Union:

- European Vocational Training Manual for Basic Guarding 1999

- Code of Conduct and Ethics for the Private Security Sector 2003

- Preventing Occupational Hazards in the Private Security Sector (manned guarding and surveillance services) 2004

- European Educational Toolkit for three Private Security Activities 2006

The training manual, code of conduct and educational toolkit are all voluntary standards, although they do carry status in many states in the EU around the creation of basic standards. The document on preventing occupational standards brings together much of the wider health and safety regulations of the EU and directs how they apply to the private security sector.

\section{European regulations}

The institutions of the European Union have been reluctant to intervene at a European level in setting minimum standards of private security regulation. However, the single market has impacted upon how some states regulate private security. There have therefore been 
decisions in the European Court of Justice which have influenced what EU states can and cannot do in regulating private security. Under Articles 39 (Now 48) Articles 43 (now 49) and 49 (now 56) of the EU Single Market it provides for:

- Free Movement of Persons, Services and Capital: Workers

- Freedom of Establishment

\section{- Freedom to Provide Services}

Several members of the European Union have sought derogations for private security regulation on the grounds that the sector contributes to public security, which is possible for activities which in themselves are directly and specifically connected with the exercise of official authority. However, the European Court of Justice has found this does not apply to security undertakings and security staff, as merely making a contribution to the maintenance of public security, which any individual may be called upon to do, does not constitute exercise of official authority (Button \& Dalda, 2014). As a consequence there are a number of states in the European Union which have been found not to be compliant with the single market regulations in their regulatory systems for private security, effectively inducing deregulation. These include: Spain, Italy, Portugal, Netherlands, Belgium and Hungary. Some of the requirements which have required reform include:

- Nationality requirements (restricting licences to one country requirement).

- Residence requirements (requiring licence holders to live in one state).

- Minimum share capital (requiring a minimum share capital for owners).

- Requiring authorisation (without accepting authorisations from other Member states)

- Licences linked to territorial area or sub-district in state, which means multiple licences would need to be sought to operate across a state.

- Not recognising other states training/professional qualifications.

- Operators must be a legal person (company), rather than individual.

- Setting minimum standards for number of workers in undertaking.

- Securities/guarantee must be with home country.

- Requiring swearing oath of allegiance to home country.

- Price approvals by local regulator.

These illustrate that in a negative way EU institutions have been influencing the regulation 
of private security. However, it is this framework in an enlarged European Union with increasing flows of workers, undertakings and services which poses a threat to the regulatory systems of some European Union countries. Those established and working in the lowest (Czech Republic) can work in the highest (Belgium). In the price driven world of private security purchases (Goold et. al, 2010) this opens up the possibility for the unscrupulous to use lower regulating countries to enter higher ranking. It provides for an advantage for those in lower ranking countries to use their lower standards and costs to expand into higher ranking. Ultimately it also undermines the 'security blanket' by providing holes which can be exploited.

\section{Discussion}

\section{Coming to Terms with the Centripetal Forces: Options for the European Union}

The EU, a political creature now over 60 years old, founded on an underpinning idea of institutional organisation much older than that, coming to life after World War 2. Often attributed as the architect of the European integration project is Robert Schuman, French foreign minister between 1948 and 1952, who sought and brokered a consensus between the six founding countries. This consensus was codified in a treaty, the European Coal and Steel Community [ECSC] in Paris in April 1951. The idea was to put some of the responsibilities to a specific entity - the European Commission (at the time the high authority) - the only supranational institution that pursues the public interest of its constituents. Over time the European integration project, now known as the European Union, has expanded and been modified by new treaties and amendments. Most recently the Lisbon treaty represent a paradigm shift in the way in which the European Union developed over the years, shifting away from being primarily driven by an economic engine, to a more encompassing process including citizens in the process. Simplifying the legislative process, giving more power to the union, but also to the EU parliament the only institution that is directly elected. The central theme is to ensure democracy and transparency, particularly the legislative process that is arguably more transparent than the one that exists in most Member States. With the strict adherence to the principle of competence, where the actions of the EU heavily depends on the desire of the member state of actually having the EU coming up with new policies, the legislative harmonisation of the private security industry is absent. Moreover, with the EU only being able to act insofar as it has received competences of the member states, once the competence has been received there is still a due process to reach agreement for a new policy. Historically the road to any policy coordination is quite long and regulation the private security industry will probably not be an exception to that rule.

Juxtaposed to the need for regulation of private security is the increasing integration of the EU and the creation of a single market. The private security industry is treated as a major business services sector and this is despite some attempts by Member States to secure a 
similar status to state security apparatus (CoESS, 1998). As such the private security industry would be exempt from these provisions, which the state security apparatus already is. However, as discussed such attempts have failed, which means the private security industry is treated like any other business service ind ustry and a private security company or operative legitimately operating in one Member State can do so in another based upon the home country authorisation. Some European countries have already developed very detailed and high quality legislation. It is these kinds of legislations and regulations that must serve as a basis for any future European harmonization in order to enhance the overall level of the industry. But national regulations are sometimes non-existent, inadequate and do not guarantee the professionalism the sector needs. By differing from one country to another they are preventing the sector from drawing on the full benefits of European integration. This however, requires a clear desire to have more Europe in the first place, a notion to which there is many perspectives and differing opinions. Adding to the complexity, even if the citizens of a Member State show that desire the political elite of the same country may be conceptually as well as ideologically against this. Because every time there is more Europe there is less national state - giving the political rulers something rather significant to lose and little to gain. Thus, unless there would be an electorate space where the leaders presented themselves in front of a European electorate, the supra-national politics of the EU is still very much an affair of nation states where national politics dominate over EU politics. Thus, the conditions to have a political debate must be created and stimulated, in part by articles like this, to if, why and how private security regulation should be European and not national - as the foundation for any change from a supra-national level.

\section{Conclusion}

\section{The future of European private security regulation}

It is within this challenging context to which we now turn. The changing terrain of the European Union relating to security, regulation and the private security ind ustry mean the current trajectory may be in need of an injection of more radical thought and consideration. A radical question might be whether a supra-national regulator for private security regulation is necessary for the whole European Union? On one hand this might be seen as the most simple solution to the new terrain, ensuring the same minimum stand ards across the European Union. On the other hand, however, such an approach would be radical, unusual (at least from a historical perspective) and politically disagreeable to many member states. Indeed even federal states such as the USA, Canada and Australia have not felt this necessary.

More palatable would be a Directive that set out the basic minimum requirements for all Member States of the European Union. Such European level regulation has already touched a number of business service sectors, such as banking, insurance, air travel to name some. Such an approach has some precedent with what has happened in Australia relating to some standards for the private security sector across states and territories, where the Council of 
Australian Governments, has sought to create greater harmonisation across the Federal states and territories, although with limited success (Sarre \& Prenzler, 2011). A Directive could set basic requirements for the licensing of individuals and firms and draw out some of the minimum standards they should meet. Nevertheless, even this in the current politics of the European Union, with some states such as the UK (and others) pursuing less European level intervention, combined with the strains on some common security apparatus such as the borderless arrangements of the Schengen area would be unlikely.

In the absence of such an initiative the current non-binding approach of building more of the infra-structure of European level standards and structures should be the priority for the policy-makers and social partners of the European private security industry. Greater investment in the development of common model European standards around the building blocks of an effective regulatory system should be developed with Member States encouraged and incentivised to embrace them. Such standards could include:

- Model regulatory systems

- Training standards for all of the common roles

- Model licensing requirements for firms and individuals

- Standards for significant security infra-structure, such as control rooms, training centres

- Guidelines for the use of force, lethal and non-lethal violence

- Codes of conduct and industry ethics policies

Thus, it is the view of the authors that the most effective way to underpin more effective pan-European private security regulation is a Directive mandating minimum standards, which member states then implement. At the same time, the authors are also realistic about the political landscape and the acceleration of more and demanding voluntary standards is the most achievable and likely policy in the short and medium term in the current politics of the European Union.

The European private security sector has grown into a multi-billion Euro industry with thousands of firms and millions of security staff. The rate of growth in size of the private security sector is paralleled only by the concurrent expansion in role and responsibility. This inevitably leads towards an increase of importance of the issue, both politically and practically, and also provides a notion of its being elaborately weaved into the fabric of modern society. Where increasing demands of states and citizens for greater security have stimulated both national and European level interest in shaping, controlling and making accountable the private security sector. Although, when comparing the ambitious rhetoric with actual achievements there is a highly varied level of private security regulation throughout Europe (Button \& Stiernstedt, 2016).

This paper has explored the role of private security in society and established that it is and will remain an ever more pressing concern on all levels of Europe, national as well as 
supranational. It then moved on to consider the main phases in the development of private security regulation in Europe. The phases as described are the Laissez-faire Europe 1930s to mid 1970s followed by the Centrifugal Europe mid 1970s to early 1990s and finally From Centrifugal to Centripetal Europe early 1990s onwards. Following on from this some of the main areas of policy development was considered. Where the institutions of the European Union have been reluctant to intervene at a European level in setting minimum standards of private security regulation. Further, those services that have been regulated have, if anything, effectively induced deregulation. As there are a number of states in the European Union which have been found not to be compliant with the single market regulations in their regulatory systems for private security. Changing this is not a simple task as, at least historically, the road to policy coordination is quite long and regulation the private security industry will probably not be an exception to that rule. With the supra-national politics of the EU is still being very much an affair of nation states where national politics dominate over EU politics.

In conclusion the paper explored some of the potential options for the future in better regulating the European private security sector. Given the challenging context and perhaps most notably constantly changing terrain of the of the European Union relating to security, regulation and the private security ind ustry mean the current trajectory may be in need of an injection of more radical thought and consideration. The simplest solution of a supranational regulator established by the European Union does not seam feasible in the short or mid term. Consequently the only realistic alternative is a directive that set out the basic minimum requirements for all Member States of the European Union. Being conscious of the pace of which the institutions of the European Union works, in the absence of, awaiting such an initiative the current non-binding approach of building more of the infra-structure of European level standards and structures should be the priority. The European harmonization of the private security services sector is the ultimate goal and the reference for any concrete initiative. Thus, it is the view of the authors that the most effective way to underpin more effective pan-European private security regulation is a Directive mandating minimum standards. 


\section{References}

Abrahamsen, R. and Williams, M., 2005, 'The Globalisation of Private Security: Country Report: Nigeria, University of Wales, Aberystwyth

Barrett, D. (2014) Immigration from eastern Europe was massively underestimated, says official report. Telegraph online

http:/www.tele graph.co.uk/news/uknews/immigration/10757336/Immigration-from-easternEurope-was-massively-underestimated-says-official-report.html

Berglund, T., n.d. The Security Industry in Europe - How to Act and React Towards Europe. Unpublished Paper Presented to the Confederation of European Security Services.

Button, M., 2007a. Assessing the regulation of private security across Europe. European Journal of Criminology, 4, 109-128.

Button, M., 2007b. Security Officers and Policing. Aldershot: Ashgate.

Button, M., 2008. Doing Security: Critical Reflections and an Agenda for Change. Basingstoke: Palgrave.

Button, M., 2011. The Private Security Industry Act 2001 and the Security Management Gap in the United Kingdom. Security Journal, 24, pp 118-132.

Button, M., 2012. Optimising Security through Effective Regulation: Lessons from Around the Globe. In, Prenzler, T. (ed) Policing and Security in Practice. Basingstoke: Palgrave.

Button, M. \& George, B., 2006. Regulation of Security: New Models for Analysis. In, Gill, M. (ed) Handbook of Security. London: Palgrave.

Button, M. and Park, H., 2009. Security Officers and The Policing Of Private Space In South Korea: Profile, Powers And Occupational Hazards. Policing and Society, 19, 247-262.

Button, M., \& Stiernstedt, P. (2016). Comparing private security regulation in the European Union. Policing and Society, 1-17. doi: 10.1080/10439463.2016.1161624

CoESS, n.d. About COESS. http://www.coess.org/

COESS (1996) Vocational Training in the European Security Industry. http://www.coess.org/_Uploads/dbsAttachedFiles/Vocational_training_in_the_private_secur ity_industry_EN.pdf

CoESS, 1998. Case C-114/97. http://www.coess.eu/?Cate goryID=325

CoESS (2001) Joint declaration of CoESS and UNI-Europa on the European harmonisation of legislation governing the private security sector 
http://www.coess.org/_Uploads/dbs_AttachedFiles/Joint_declaration_on_European_harmonis ation_of_legislation_EN.pdf

CoESS (2004) Annual Report; URL:

http://www.coess.org/documents/annual_report_2004.pdf.

CoESS (2006) News; URL http//www.coess.org/ .

CoESS, 2011. Private Security Services in Europe. Brussels: COESS.

COM(2012) 746. (2012). EU Regulatory Fitness. Strasbourg: European Commission.

$\operatorname{COM}(2015)$ 185. (2011). Communication from the Commission to the European Parliament, the Council, the European Economic and Social Committee, and the Committee of the Regions - The European Agenda on Security. Strasbourg: European Commision.

Control Risks, 2016. Riskmap Report 2016. London: Control Risks.

Davis, M., 1998. City of Quartz: Excavating the Future in Los Angeles, London: Pimlico.

De Waard, J., 1993. The Private Security Sector in Fifteen European Countries: Size, Rules and Legislation. Security Journal, 4(2) pp 58-62.

De Waard, J. 1996. The private security industry in the Netherlands: developments and future perspectives. Security Journal, 7:227-234.

De Waard, J., 1999. The Private Security Industry in International Perspective. European Journal of Criminal Policy and Research, 7(2) pp 143-174.

De Waard, J \& Van Der Hoek, J., 1991. Private Security Size and Legislation in the Netherlands and Europe. The Hague: Dutch Ministry of Justice.

De Waard, J. \& Van Der Hoek, J. (1991) Private Security. The Hauge: Ministry of Justice.

Economist, T. (2015, September 26). Mr Saakashvili goes to Odessa. Retrieved October 13, 2016, from http//www.economist.com/news/europe/21667967-georgian-reformer-tacklesukraines-real-public-enemy-number-one-corruption-mr-saakashvili-goes

ECORYS, 2011. Security Regulation, Conformity Assessment \& Certification (Vol. Final Report - Volume I: Main Report). Brussels: European Commission, DG Enterprise \& Industry.

EPC, 2013. The Stockholm programme: what's next? Paper presented at the Informal meeting of Justice and Home Affairs Ministers, Vilnius.

European Private Security Services Education and Training, 1999. European Vocational 
Training Manual for Basic Guarding. Available at:

http:/www.eesc.europa.eu/resources/docs/138-private-act.pdf [Retrieved 24 February 2015].

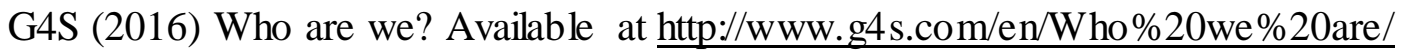
[retrieved 15-1-206].

George, B., \& Button, M. (2000). Private security Vol 1: V. 1. Leicester: Palgrave Macmillan.

Gimenez-Salinas, A., 2004. New Approaches Regarding Private/Public Security. Policing and Society, 14,158-174.

Goold, B., Loader, I. \& Thulma, A., 2010. Consuming security? Tools for a sociology of security consumption. Theoretical Criminology, 14, 3-30.

Hainmuller, J. and Lemnitzer, J., M., 2003. Why do Europeans Fly Safer? The Politics of Airport Security in Europe and the US. Terrorism and Political Violence, 15, pp 1-36.

Johnston, L. and Shearing, C., D., 2003. Governing Security. London: Routledge.

Jones, T. and Newburn, T., (eds)2006. Plural Policing. Abingdon: Routledge.

Jones, T. and Newburn, T., 1998. Private Security and Public Policing. Oxford: Clarendon Press.

Kasali, M. A. Analyzing the Evolution of Private Security Guards and their Limitations to Security Management in Nigeria. African Journal of Criminology and Justice Studies, [S.1.], v. 5, n. 1 \& 2, sep. 2012. ISSN 1554-3897.

Loader, I., \& White, A. (2015). How can we better align private security with the public interest? Towards a civilizing model of regulation. Regulation \& Governance. doi: 10.1111/rego.12109

Ocqueteau, F., 2006. France. In, Jones, T. and Newburn, T. (eds) Plural Policing. Abingdon: Routledge.

OJ C 115/1. (2010). The stockholm programme — an open and secure europe serving and protecting citizens.

Okolski, M. 2014 Polish Emmigration to the UK after 2004. Why did so many come?

Migration Research Unit. http:/www.geog.ucl.ac.uk/research/transnationalspaces/migration-research-unit/discussion-papers/MOJS\%20revise\%20041114_accept.pdf

Prenzler, T. and Sarre, R., 1999. A Survey of Security Legislation and Regulatory Strategies 
in Australia. Security Journal 12, 7-17

Prenzler, T. and Sarre, R., 2008. Developing a Risk Profile and Model Regulatory System for the Security Industry. Security Journal, 21: 264-277.

Prenzler, T., \& Sarre, R. 2012. The evolution of security industry regulation in Australia: A critique. International Journal for Crime, Justice and Social Democracy, 1(1). doi: 10.5204/ijcjsd.v1 il.72

Prenzler, T., Baxter, T., and Draper, R., 1998. Special Legislation for the Security Industry: A Case Study. International Journal of Risk, Security and Crime Prevention, 3: 21-33.

Rigakos, G., S., 2002. The New Parapolice. Toronto: University of Toronto Press.

Sarre, R. and Prenzler, T., 2011. Private Security and Public Interest: Exploring Private Security Trends and Directions for Reform in the New Era of Plural Policing. Sydney: ARC Report.

Security Industry Authority, 2014. The SIA in Statistics: January 2014. Available from: http:/www.sia.homeoffice.gov.uk/Pages/about-news.aspx?newsID=473\&ArtTypeID=13 [Retrieved 23 March 2014].

Shearing, C., D. and Stenning, P., C., 1982. Private Security and Private Justice. Montreal: The Institute on Public Policy.

United Nations Office on Drugs and Crime, 2014. State Regulation Concerning the Civilian Private Security Services and their Contribution to Crime Prevention and Community Safety. Vienna: UNODC.

Van Steden, R., 2007. Privatizing Policing. Amsterdam: BJU.

Van Steden, R. and Sarre, R., 2007. The Growth of Private Security: Trends in the European Union. Security Journal, 20: 222-235.

White, A., 2010. The Politics of Private Security. Basingstoke: Palgrave.

Wolfswinkel, J. F., Furtmueller, E., \& Wilderom, C. P. M. (2013). Using grounded theory as a method for rigorously reviewing literature. European Journal of Information Systems, 22, 45-55. 